\title{
Przegląd możliwości zastosowania technologii klejenia
}

\section{Review of prospects of adhesive bonding technology application}

\begin{abstract}
Streszczenie
W artykule przedstawiono pespektywy rozwoju technologii klejenia, która ze względu na liczne zalety coraz częściej stosowana jest w różnych gałęziach przemysłu np. motoryzacyjnym, kolejowym, lotniczym, elektronicznym. Omówiono możliwości klejenia nowych materiałów - kompozytów, stosowanych przy produkcji np. pojazdów szynowych, turbin wiatrowych i statków, których zastosowanie jest możliwe tylko za pomocą technologii klejenia. W artykule przedstawiono czynniki wpływające na uzyskanie wysokiej jakości połączenia, a także skupiono się na ograniczeniach i wadach tej metody oraz aspektach dotyczących bezpieczeństwa pracy przy procesach klejenia.
\end{abstract}

Słowa kluczowe: technologia klejenia; zastosowanie klejenia; kleje

\begin{abstract}
The article presents the perspectives of adhesive bonding technology development. This technology, taking into consideration its advantages, is more and more often applied in different industrial branches e.g. automotive, railway engineering, aviation and electronics. Possibilities of adhesive bonding of new materials - composites are elaborated in the article. Composites are mainly used in production of e.g. rail vehicles, wind turbines and ships and their application is possible only using adhesive bonding technology.

Article describes the factors which influence on obtaining high quality joints and also restrictions, disadvantages and occupational safety aspects of this technology.
\end{abstract}

Keywords: adhesive bonding; application of adhesive bonding; adhesives

\section{Wprowadzenie}

Technologia klejenia zaliczana jest do nowoczesnych technologii łączenia materiałów. Zajmuje ona ważne miejsce w łączeniu materiałów, obok klasycznych metod spajania takich jak: spawanie, lutowanie czy zgrzewanie.

Do szybkiego rozwoju technologii klejenia i produkcji klejów przyczyniły się wysokie wymagania konstrukcyjne stawiane przede wszystkim przez współczesny przemysł lotniczy. Dążył on do zastąpienia tradycyjnego nitowania, spawania czy zgrzewania - klejeniem, szczególnie przydatnym do łączenia dużych, cienkościennych elementów powłokowych. Największe znaczenie przy budowie samolotów miało uzyskanie wytrzymałej, lekkiej konstrukcji o dużej sztywności i zwiększonej odporności zmęczeniowej, co umożliwiło zmniejszenie masy samolotu o kilkanaście procent, dając przy tym duże oszczędności zarówno w jego produkcji jak i eksploatacji.

Wpływ na gwałtowny rozwój technologii klejenia miało również wprowadzanie nowych, lekkich materiałów konstrukcyjnych, które należało skutecznie ze sobą połączyć. Jednym z takich materiałów są kompozyty włókniste, których zastosowanie zapewnia lekkość konstrukcji oraz wysoką wytrzymałość i sztywność przy jednocześnie małej gęstości materiału. Zastosowanie kompozytów włóknistych pozwala na dużą swobodę odnośnie geometrii w trakcie projektowania konstrukcji oraz zapewnia niską przewodność cieplną i wysoką zdolność przyjmowania energii i tłumienia drgań. W tym przypadku klejenie jest często jedyną metodą ich spajania.

Materiały kompozytowe z włóknami szklanymi, węglowy$\mathrm{mi}$, aramidowymi stosowane są m.in. do budowy pojazdów szynowych, turbin wiatrowych, jachtów, a także w lotnictwie, kosmonautyce, przy produkcji sprzętu sportowego oraz samochodów wyścigowych. Coraz szersze zastosowanie kompozytów wzmacnianych włóknami zauważa się także w budownictwie - stosowane są one do zwiększenia nośności konstrukcji drewnianych, metalowych i betonowych.

\section{Zastosowanie technologii klejenia}

Technologia klejenia często jest wykorzystywana w różnych gałęziach przemysłu ze względu na swoje liczne zalety, do których zalicza się m.in.:

- możliwość łączenia materiałów o zróżnicowanych właściwościach fizykochemicznych, np.: szkło-metal, tworzywo sztuczne-metal, tworzywo sztuczne-guma;

- możliwość łączenia elementów o różnych wymiarach i kształtach (zarówno bardzo małych elementów jak i elementów wielkopowierzchniowych);

- brak niekorzystnego odziaływania ciepła na właściwości materiałów łączonych, występujące przy spawaniu,

Mgr inż. Beata Rams - Instytut Spawalnictwa, Gliwice.

Autor korespondencyjny/Corresponding author: beata.rams@is.gliwice.pl 
zgrzewaniu czy lutowaniu;

- równomierne obciążenie złącza, w porównaniu do połączeń śrubowych lub nitowych;

- szczelność połączeń i ich ochrona przed wnikaniem wilgoci oraz korozją;

- posiadanie właściwości tłumienia drgań i dźwięków przez połączenie klejowe;

- przyjmowanie przez elastyczną warstwę kleju niekorzystnych różnic współczynnika rozszerzalności cieplnej klejonych materiałów;

- wyeliminowanie dodatkowych obróbek powierzchniowych połączenia po procesie klejenia;

- większa estetyka złącza klejowego w porównaniu z innymi metodami łączenia („niewidoczna” technika łączenia);

- duża odporność na działanie substancji chemicznych, np. olejów, alkoholi, benzyny;

- możliwość zautomatyzowania procesu mieszania, dozowania i nakładania kleju.

Właśnie ze względu na liczne zalety klejenie znalazło zastosowanie np. w przemyśle samochodowym, gdzie obecnie do wyprodukowania jednego samochodu zużywa się od 90 do 120 metrów spoin klejowych. Często nie są to jedynie połączenia klejone, ale także połączenia hybrydowe czyli połączenia klejone wykonywane wraz z połączeniami zgrzewanymi lub ze złączami śrubowymi.

Przy produkcji samochodów technologie klejenia stosuje się m.in. do:

- klejenia elementów nadwozia, gdzie klejenie nie tylko ma zapewnić większą sztywność, ale dodatkowo uszczelnić połączenie oraz zmniejszyć wibracje;

- klejenia blach poszyciowych zwłaszcza w pojazdach większych gabarytowo jak np. samochody ciężarowe, autobusy oraz pojazdy specjalnego przeznaczenia, gdzie wymagana jest duża tolerancja wymiarów, tłumienie drgań, odporność na zmienne warunki atmosferyczne, szczelność oraz estetyka połączenia;

- klejenia amortyzatorów, gdzie klejenie wykorzystuje jedną z podstawowych swoich zalet - łączenie różnych materiałów i w tym przypadku ma zapewnić dobre połączenie między metalami a gumą jako elementem sprężynującym;

- osadzania łożysk i kół zębatych, gdzie klejenie zapewnia wypełnianie szczelin, kasowanie luzów, szczelność oraz zabezpiecza przed wibracjami.

Dodatkowo klejenie w przemyśle samochodowym stosuje się do wklejania szyb, lusterek, okładzin hamulcowych, reflektorów, chłodnic, zabezpieczenia i uszczelnienia połączeń gwintowych oraz montażu elementów wykończeniowych wykonanych zazwyczaj z tworzywa sztucznego, gdzie klejenie jako metoda łączenia różnych materiałów sprawdza się bardzo dobrze.

Coraz częściej technologię klejenia wykorzystuje się także w budownictwie, gdzie we współczesnych obiektach architektonicznych, za pomocą klejenia łączy się szklane systemy ścian ze szkieletem stalowym, stanowiącym alternatywę dla zacisków mechanicznych. Często w budownictwie używa się szkła klejonego tzw. szkła bezpiecznego, które powstaje w wyniku połączenia dwóch lub kilku tafli szkła za pomocą warstwy klejącej którą może być odpowiednia żywica, wlewana w postaci ciekłej między dwie tafle szklane lub folia umieszczona pomiędzy szybami a następnie podgrzana do odpowiedniej temperatury w autoklawie. Szkło klejone (zarówno folią jak i żywicą) uderzone pęka, zachowując przy tym swój kształt, ponieważ odłamki przyklejone są do warstwy sklejającej. Stosując odpowiedni rodzaj żywicy lub folii można uzyskać szyby: antywłamaniowe, kuloodporne, chroniące przed hałasem lub promieniami UV. Takie szyby stosuje się jako np.: elementy ogrodzenia, balu- strad, szklane drzwi, podłogi lub schody oraz jako elementy dźwiękochłonnych ekranów drogowych. Klejenie szkła ze szkłem lub szkła z metalem dokonuje się przy użyciu specjalnych klejów, które utwardzają się pod wpływem promieniowania ultrafioletowego. W ten sposób kleimy szkło ze szkłem (np. gabloty szklane) oraz szkło z elementami metalowymi (np. metalowe nogi do blatów szklanych, zawiasy do drzwiczek szklanych).

Rozwój technologii klejenia przyczynił się także do wykorzystywania w budownictwie materiałów kompozytowych (taśm i mat), które w odniesieniu do konstrukcji metalowych mają swój udział szczególnie we wzmacnianiu i naprawach mostów i budynków. Wykorzystuje się tu bardzo wysoki wskaźnik stosunku sztywności do ciężaru kompozytów, ich odporność na zmęczenie i korozję oraz dające się kontrolować zachowanie w podwyższonej temperaturze. W zastosowaniach budowlanych stosuje się zarówno materiały na bazie włókien węglowych (CFRP - Carbon Fibre Reinforced Polymers) jak i na bazie włókien szklanych (GFRP - Glass Fibre Reinforced Polymers), które nadają się do wzmacniania (zwiększenie pierwotnej nośności bądź sztywności) wszystkich rodzajów konstrukcji: żelbetonowych, stalowych, drewnianych, murowanych, betonowych. Natomiast materiały na bazie włókien aramidowych (AFRP - Aramid Fibre Reinforced Polymers) stosuje się do wzmacniania konstrukcji narażonych na oddziaływania dynamiczne, sejsmiczne i wybuchy.

Głównymi przyczynami wymuszającymi wzmocnienie konstrukcji są:

- zmiany sposobu użytkowania obiektu (zwiększenie istniejących obciążeń);

- wprowadzenie zmian w istniejącej konstrukcji;

- zagrożenie wystąpienia obciążeń wyjątkowych, nieplanowanych na etapie projektowania obiektu;

- przemieszczanie podłoża (nierównomierne osiadanie, wstrząsy parasejsmiczne);

- błędy projektowe i wykonawcze.

Technologia klejenia znalazła także zastosowanie w rozwiązaniach pomostów i kładek z płyt kompozytowych mocowanych przez klejenie na wspornikach aluminiowych (np. most podwieszany przez rzekę Saone we Francji - lata 70.) lub na wspornikach stalowych (np. most West Mill w Wielkiej Brytanii, oddany do użytku w 2002 r).

Innym wykorzystaniem technologii klejenia w budownictwie jest klejenie drewna. Wykonuje się zarówno konstrukcje $z$ drewna klejonego jak i drewna klejonego wzmacnianego włóknami. Konstrukcje wykonane z drewna klejonego wzmacnianego włóknami węglowymi bądź aramidowymi pozwalają na zwiększenie nośności belek przy znacznej redukcji przekroju poprzecznego belki zmniejszając przy tym znacznie zużycie drewna nawet o 40\%. Konstrukcje tego typu są z powodzeniem stosowane od 15 lat w Stanach Zjednoczonych, a obecnie wkraczają też na rynek europejski.

Konstrukcje z drewna klejonego (warstwowego) stosuje się np. do budowy domów mieszkalnych, biurowców, obiektów sportowych, basenów, pawilonów wystawowych.

Technologia klejenia oprócz wielu zalet posiada też pewne ograniczenia. Do podstawowych wad klejenia ograniczających jej zastosowanie, zalicza się:

- ograniczoną odporność na działanie wysokich temperatur, szczególnie powyżej $200^{\circ} \mathrm{C}$;

- małą wytrzymałość mechaniczną połączeń, zwykle nie przekraczającą $40 \mathrm{MPa}$;

- małą odporność połączeń klejonych na rozszczepianie i oddzieranie;

- zazwyczaj brak pełnej wytrzymałości mechanicznej bezpośrednio po sklejeniu; 
- ograniczoną odporność na warunki zewnętrzne, jak promieniowanie UV, wilgoć;

- ograniczoną żywotność składowania klejów, ich skłonność do rozwarstwiania, żelowania i sedymentacji;

- konieczność stosowania specjalnych sposobów przygotowania powierzchni w celu zapewnienia dobrej adhezji kleju;

- występowanie substancji szkodliwych dla zdrowia, znajdujących się w wielu gatunkach klejów wymagających specjalnych warunków bezpieczeństwa w procesie technologicznym;

- niepełną możliwość kontroli w badaniach nieniszczących.

Stale rosnące zainteresowanie różnych gałęzi przemysłu możliwością zastosowania technologii klejenia wymusza na producentach ciągły rozwój tej technologii poprzez modyfikowanie istniejących klejów oraz tworzenie nowych produktów spełniających oczekiwania potencjalnych użytkowników.

$\mathrm{Na}$ przykład potrzeba zastosowania klejów odpornych na wysokie temperatury, nawet do $300^{\circ} \mathrm{C}$, a zarazem posiadających właściwości uszczelniające i odporne na działanie wilgoć, wymusiła na producentach opracowanie odpowiedniego kleju spełniającego wszystkie te warunki. Takimi klejami są np. kleje silikonowe nadają się doskonale do takich aplikacji jak:

- mocowanie ceramicznych płyt grzewczych do blatów kuchenek,

- wklejanie oświetlenia (montaż żarówek),

- klejenie zintegrowanych układów elektronicznych,

- klejenie zespołów elektronicznych do paneli słonecznych,

- klejenie szklanych drzwiczek oraz uchwytów piekarnika itd.

Producenci oferują także kleje specjalistyczne, gdzie ograniczenie stosowania w bardzo wysokich temperaturach nie jest już przeszkodą, np. kleje na bazie substancji nieorganicznych stosowane do łączenia metali z ceramiką, które są odporne nawet do $1600^{\circ} \mathrm{C}$. Takie właśnie kleje zostały zastosowane np. do połączenia płytek krzemowych z poszyciem promu kosmicznego Columbia.

Omawiając ograniczenia dotyczące klejenia, takie jak brak przewodności cieplnej i elektrycznej, które eliminowały technologię klejenia w znacznym stopniu z zastosowań produkcyjnych należy wspomnieć o najnowszych osiągnięcia w dziedzinie klejenia umożliwiających uzyskanie połączeń o dużej przewodności cieplnej i małej oporności elektrycznej przy zachowaniu wysokich własności mechanicznych. Wykorzystuje się tu kleje w których osnową jest żywica epoksydowa, a dobrą przewodność zapewniają napełniacze metalowe o odpowiednio wysokim przewodnictwie elektrycznym. Jako napełniacze stosuje się cząsteczki np. z miedzi, niklu, srebra, grafitu o różnych wielkościach i kształcie. Na przykład przewodność elektryczna klejów oparta na żywicach epoksydowych z napełniaczem w postaci płatków srebra osiąga wartość ok. $10 \mathrm{MS} / \mathrm{m}$ i jest zbliżona, co do wartości, przewodnictwu żelaza. Przewodność takich klejów elektroprzewodzących dorównuje lub przewyższa nawet przewodności elektrycznej lutów miękkich (dla lutu LC60 wynosi $7,2 \mathrm{MS} / \mathrm{m}$ ) i twardych lutów srebrnych (dla lutu LS15F - 4,1 MS/m i dla LS45 - 10,1 MS/m). Dzięki temu klejenie jest coraz powszechniej stosowane w przemyśle elektrycznym i elektronicznym.

Mimo małej jednostkowej wytrzymałości mechanicznej połączeń, w wielu przypadkach, klejenie w budowie maszyn może konkurować z klasycznymi metodami spajania. Właściwości wytrzymałościowe można znacznie poprawić dodając do osnowy kleju (zazwyczaj żywicy epoksydowej) napełniaczy metalowych (np. aluminiowych, stalo- wych) i niemetalowych (np. ceramicznych) w postaci m.in. cząstek, włókien lub siatek w celu uzyskania spoin klejowych o budowie kompozytowej. Produkty takie w postaci past lub materiałów płynnych służą m.in. do naprawy lub odbudowy maszyn i urządzeń bez konieczności ich spawania. Cechują się dobrą adhezją m.in. do metali, szkła, ceramiki i charakteryzują się doskonałą odpornością na agresywne związki chemiczne. Przykładowe zastosowanie takich produktów to: uszczelnianie pęknięć w zbiornikach, korpusach i zaworach, uzupełnianie ubytków spowodowanych kawitacją i korozją, odbudowa zużytych elementów stalowych lub aluminiowych. Kleje $\mathrm{z}$ wypełniaczami metalowymi po utwardzeniu mogą być wiercone, gwintowane, toczone, frezowane i poddawane innej obróbce maszynowej.

Jak już wspomniano, wiele gatunków klejów w stanie nieutwardzonym, aktywatorów oraz substancji dodatkowych używanych do oczyszczania powierzchni przed procesem klejenia (np. rozpuszczalniki, środki trawiące) w swoim składzie posiada substancje szkodliwe dla zdrowia. Szkodliwe działanie kleju może być zarówno skutkiem bezpośredniego kontaktu nieutwardzonego jeszcze kleju ze skórą jak i wynikiem odziaływania oparów na organizm człowieka. Największą możliwość zetknięcia się z nieutwardzonym klejem występuje w czasie przygotowywania masy klejowej (odważanie i mieszanie składników) oraz ręcznego nanoszenia kleju na powierzchnie łączone.

Pomieszczenia, w których wykonywane są prace z zastosowaniem technologii klejenia powinny być zatem dobrze wentylowane, tzn. powinna znajdować się w nich wentylacja ogólna nawiewno-wywiewna oraz stanowiskowa, zwłaszcza w miejscach szczególnie intensywnego wydzielania się substancji lotnych. Zaleca się aby pracownicy wyposażeni byli w odpowiednią odzież ochronną tj. fartuchy robocze, rękawice, okulary ochronne oraz w przypadku dłuższego narażenia na opary kleju specjalne maski chroniące ich przed działaniem substancji szkodliwych.

Producenci wychodząc naprzeciw oczekiwaniom klientów dotyczących zapewnienia bezpieczeństwa pracy coraz częściej modyfikują swoje produkty lub opracowują nowe receptury klejów i substancji dodatkowych tak aby były one bezpieczne dla zdrowia i środowiska naturalnego. Takim przykładem może być zastępowanie acetonu jako środka czyszczącego uważanego za produkt szkodliwy - alkoholem izopropylowym lub środkami myjącymi na bazie wody. Innym przykładem modyfikacji klejów jest zastosowanie wody jako rozpuszczalnika w przypadku klejów rozpuszczalnikowych lub wprowadzenie klejów nowej generacji bezpiecznych dla zdrowia np. polimeru modyfikowanego silanami (polimer MS). Polimery MS posiadają podobne właściwości co kleje poliuretanowe, natomiast w swoim składzie nie zawierają szkodliwych izocyjanianów. Polimery MS ze względu na swoje liczne zalety jak: zapewnienie doskonałej adhezji do metali, szkła i tworzyw sztucznych bez konieczności użycia primera, odporność na promieniowanie UV (w przeciwieństwie do poliuretanów) oraz możliwość malowania i lakierowania po klejeniu znalazły już szerokie zastosowanie w budowie pojazdów samochodowych, w uszczelnianiu połączeń kołnierzowych, nitowanych, śrubowych i zgrzewanych punktowo.

W poprawie bezpieczeństwa przy procesach klejenia pomocna jest też kolejna zaleta klejenia jaką jest łatwość zautomatyzowania i zrobotyzowania stanowiska do klejenia. Zastosowanie robota przemysłowego współpracującego z dodatkowym wyposażeniem do przechowywania, przepompowywania, mieszania oraz nakładania substancji do klejenia eliminuje bezpośredni kontakt i narażenie osób pracujących przy klejeniu na czynniki szkodliwe (przekłada się na bezpośrednią ochronę zdrowia pracowników). Wyko- 
rzystanie robotów do aplikowania klejów niweluje ryzyko narażenia pracownika na substancje szkodliwe zawarte w klejach i materiałach do klejenia. Dodatkową zaletą zastosowania robotów jest możliwość kontroli ilości nakładanego kleju, co pozwala na uzyskiwanie każdorazowo wysokiej jakości połączenia klejowego eliminując przy tym błąd ludzki.

\section{Jakość połączenia klejowego}

W połączeniach klejowych mogą pojawić się defekty pogarszające jakość połączenia niezależnie od tego czy proces klejenia wykonywany jest manualnie czy jest on zrobotyzowany.

Ponieważ klejenie zalicza się do procesów specjalnych nie jest możliwa ocena i kontrola jakości produktu końcowego. Jakość połączenia klejowego nie może być kontrolowana lub sprawdzona później w pełnym zakresie poprzez metody nieniszczące. Oznacza to, że błędy w procesie rozpoznane zostaną ewentualnie dopiero w fazie użytkowania. Dlatego każdy ze znaczących etapów procesu musi zostać odpowiednio opisany, stale kontrolowany i udokumentowany. Wysoką jakość połączenia należy więc zapewnić i kontrolować już na etapie produkcji.

Do najważniejszych metod badań nieniszczących stosowanych do wykrycia wad w połączeniach klejowych zalicza się metody: ultradźwiękowe, spektroskopowe, termowizyjne, emisji akustycznej, holografii optycznej, wibroakustyczne. Stosowanie tych metod nie jest wystarczająco rozpoznane w odniesieniu do połączeń klejowych i większość z nich pozostaje w sferze badań laboratoryjnych. Poprzez badania nieniszczące można określić uszkodzenia w częściach spajanych (np. rysy, pęknięcia, korozję, wgniecenia), wady w spoinie klejowej (np. pęcherze powietrza, ciała obce, zwęglenie kleju, brak lub przerwanie warstwy kleju, za gruba bądź za cienka warstwa kleju) oraz w strefie adhezji (np. ubytek kleju na dużej powierzchni). Natomiast badania te nie pozwalają na określenie jakości adhezji ani wytrzymałości złącza.

Oceny jakości złącza klejowego dokonuje się zazwyczaj poprzez sprawdzenie metodami niszczącymi, za pomocą próbek pilotujących bądź badań wytrzymałościowych gotowych przedmiotów wybranych z produkcji. Informacje z takich badań pozwalają na określenie jakości adhezji oraz wytrzymałości, ale tylko badanego elementu, a nie całej wykonanej partii.

Aby uzyskać wysokiej jakości połączenie klejowe trzeba zwrócić uwagę m.in. na:

- odpowiednie projektowanie oraz rozkład naprężeń w połączeniach klejowych;

- odpowiedni do danej aplikacji dobór kleju (czas otwarty kleju, sposób utwardzania, odporność na czynniki chemiczne i zewnętrzne itd.);

- odpowiednie przygotowanie powierzchni (zwłaszcza materiałów o niskiej energii powierzchniowej);

- unikanie zanieczyszczenia powierzchni klejonej silikonami (silikony mają małe napięcie powierzchniowe i uniemożliwiają zwilżanie);

- odpowiedni transport i magazynowanie klejów i substancji pomocniczych;

- odpowiednie zabezpieczenie przygotowanych powierzchni przed ponownym zabrudzeniem;

- przestrzeganie odpowiednich dla danego kleju warunków nakładania i utwardzania kleju.

\section{Podsumowanie}

W artykule przedstawiono zaledwie kilka przykładów zastosowania technologii klejenia. Natomiast otaczający nas świat został w różny sposób posklejany, ale często klejenie pozostaje dla nas niewidoczne. Kleje stosuje się poczynając od produkcji plastrów po wysoko rozwiniętą technikę medyczną (np. sprzęt medyczny, sklejanie ran w chirurgii), przy produkcji mebli, sprzętu sportowego, mikro chipów a także przy większych konstrukcjach jak budowa samolotów, jachtów oraz statków.

Zainteresowanie techniką klejenia stale wzrasta, a ograniczone zastosowanie klejów w niektórych gałęziach przemysłu wynika raczej z braku wiedzy na temat tej metody łączenia a nie ograniczeń wynikających z samej technologii.

\section{Literatura}

[1] Z. Mirski, T. Piwowarczyk: Composite adhesive joints of hardmetals with steel, Archives of Civil and Mechanical Engineering, Vol. 10, 3/2010, s. 83-94

[2] Z. Mirski, T. Piwowarczyk: Klejenie w budowie pojazdów samochodowych, Przegląd Spawalnictwa, nr 5-7, 2004.

[3] J. Kowalczyk: Nieniszczące metody oceny połączeń klejonych, Zeszyty Naukowe Politechniki Poznańskiej, Maszyny Robocze i Transport, $63 / 2008$

[4] Z. Brojer, Z. Hertz, P. Penczek: Żywice epoksydowe. Wydawnictwo Naukowo-Techniczne, Warszawa 1982

[5] M. Cwyl: Klejone połączenia szklanych elementów elewacji z metalowym szkieletem, Praca doktorska, Politechnika Warszawska, Warszawa 2007.

[6] M. Piekarczyk: Zastosowanie techniki klejenia w metalowych konstrukcjach budowlanych, Politechnika Krakowska, Kraków 2013

[7] Materiały szkoleniowe Instytutu Fraunhofera, Bremen 2015

[8] Michał Kurpiński: Identyfikacja wad technologicznych połączeń klejowych z zastosowaniem termografii aktywnej dla potrzeb przemysłu motoryzacyjnego, PAK, Vol. 60, 12/2014.
[9] https://www.astor.com.pl (2016).

[10] http://www.loctite.pl/plp/content_data/135862_7356_2K_SiliconLeaflet_PL_last_version.pdf (2016).

[11] http://www.inzynierbudownictwa.pl/technika,materialy_i_technologie,artykul,wzmacnianie_konstrukcji_budowlanych_materialami_kompozytowymi_frp,8189 (2016)

[12] https://e-kleje.pl/content/8-smp-polimer-modyfikowany-silanami (2016)

[13] http:www.oknonet.pl/szklo/producenci_szklo_budowlane/news,23382. html (2016).

[14] J. Kuczmaszewski: Czynniki niepewności prognozy wytrzymałości klejowych połączeń metali, Przegląd Spawalnictwa, nr 8, 2008.

[15] Z. Mirski, R. Wróblewski, A. Gołembiewski: Odporność połączeń klejowych na oddziaływanie wysokiej temperatury, Przegląd Spawalnictwa, nr 10, 2015.

[16] A. Sajek: Technologia klejenia i właściwości złącza klejowego kompozytowych pian aluminiowych, Przegląd Spawalnictwa, nr 3, 2014. 